\title{
The Revised Version of the Committing and Experiencing Cyber-Violence Scale and Its Relation to Psychosocial Functioning and Online Behavioral Problems
}

\author{
Daniela Šincek (1)
}

Citation: Šincek, D. The Revised Version of the Committing and Experiencing Cyber-Violence Scale and Its Relation to Psychosocial Functioning and Online Behavioral Problems. Societies 2021, 11, 107. https://doi.org/10.3390/ soc 11030107

Academic Editor: Gregor Wolbring

Received: 31 July 2021

Accepted: 1 September 2021

Published: 2 September 2021

Publisher's Note: MDPI stays neutral with regard to jurisdictional claims in published maps and institutional affiliations.

Copyright: (C) 2021 by the author. Licensee MDPI, Basel, Switzerland. This article is an open access article distributed under the terms and conditions of the Creative Commons Attribution (CC BY) license (https:/ / creativecommons.org/licenses/by/ $4.0 /)$.
Department of Psychology, Faculty of Humanities and Social Sciences, Josip Juraj Strossmayer University of Osijek, 31000 Osijek, Croatia; dsincek@ffos.hr

\begin{abstract}
Cyber-violence is the type of online risk behavior inclined to harm others. Development of new forms of cyber-violent behavior leads to the need to revise specific-item measures of cyberviolence periodically. The aim of this research was to explore the psychometric properties of the revised Committing and Experiencing Cyber-Violence Scale: its latent structure, reliability, and descriptive statistics of underlying dimensions, as well as the relation of some known correlates of cyber-violence, like indicators of psychosocial functioning and online behavioral problems, with cyber-violence. Online questionnaires (cyber-violence, depression, anxiety and stress, problematic Internet use, and problematic gaming) were filled out by 1725 adolescents from a convenient sample. Using exploratory factor analysis and hierarchical regression analysis, the questionnaire's latent structure and contribution of relevant correlates for explaining cyber-violence variance was examined. Results: Exploratory factor analysis showed a five-factor solution with satisfactory reliability: shaming, information manipulation, hate speech, technology abuse, and information sharing. Participants commit and experience cyber-violence rarely, leading to a positive distribution of data in the factors. The Committing and Experiencing Cyber-violence subscales have a large positive correlation. Gender (male), grades, maternal education, depression, anxiety, stress, problematic Internet use, and problematic gaming are positive predictors of experiencing cyber-violence, whereas gender (male), grades, hours spent online on weekdays, depression, anxiety, stress, problematic Internet use, and problematic gaming are positive predictors of committing cyber-violence. Conclusions: Cyber-violence is connected with lower psychosocial functioning and more risky behavior online (problematic Internet use, problematic online gaming).
\end{abstract}

Keywords: cyber-violence; scale; psychosocial functioning; online behavioral problems

\section{Introduction}

During the COVID-19 pandemic, there were major changes in the lives of people of all ages. For many children, young people, and adults, work and education has moved from the physical to the digital world over time. Children and young people around the world have experienced lockdowns of varying magnitude. In Croatia, from 13 March 2020 to 11 May 2020 (primary schools) and 18 May 2020 (secondary school), in-person classes were stopped and students attended classes by watching a TV program and/or doing assignments that were sent by teachers or by attending classes on online platforms [1,2]. At that time, movement within the municipality of residence was restricted [3] and open-air children's and sports playgrounds were fenced to prevent the gathering of children and young people [4]. All of this contributed to the increased amount of time in front of screens. This has raised concerns among experts about the consequences of both lockdown and the pandemic, as well as the impact on education and social development of children and young people [5]. Although these circumstances contribute to the reduction of traditional peer violence [6], an increase in domestic violence [7] or cyber-violence, at least for some adolescents [8], was found. 


\subsection{Cyber-Violence Definition and Measurement}

Cyber-violence was recognized at the end of the 1990s as a type of online deviant behavior [9]. Later on, the terms "cyber-bullying" and "cyber-victimization" were mostly used. Cyber-bullying is defined as "willful and repeated harm inflicted through computers, cell phones, and other electronic devices" [10] (p. 11). The influences of Olweus' definition of traditional bullying [11] are easily recognized in this definition. Patchin and Hinduja [12] stress the importance of using criteria for traditional bullying in defining cyber-bullyingrepetition, harm, intention, and imbalance of power. They do recognize that repetition in the digital world could be somewhat different than in traditional bullying since a one-time cyber-attack can reach a large audience and be shared or found on the Internet later. This definition of intention to harm is very questionable. They stress that the victim can perceive particular behavior as intentional, but if the perpetrator did not want to cause harm, it cannot be seen as cyber-bullying. This view could be appropriate in the legal system, and since those two scholars are both experts in criminal justice, it directs them toward the perpetrator's position. Other researchers [13] warn that this approach to defining cyberbullying does not consider the position of the victim. Respecting the victim's position and psycho-social perspective, as well as the possibilities that the material online is later shared or approached, authors decided [14] to use the term "cyber-violence" and not to insist on the perpetrator's intention to harm and the repetition of behavior two or three times per month to consider something as harmful behavior. It should be noted that interactions with adolescents through a cyber-violence preventive program informed us that they often perceive some forms of cyber-violent behavior (e.g., making fun of someone) as a joke (if they are not in the position of the victim of that joke). On the other hand, in a qualitative study conducted by the author of this paper during 2020 to gain insight into adolescents' perception of Internet and cyber-violence, and to revise the cyber-violence scale, adolescents found it very common to use jokes as a way to disguise humiliation. Accordingly, an item measuring that behavior was added to the scale. In addition, previous findings indicate that perpetrators and perpetrators/victims assess most violent behaviors as less severe than young people who are not involved in violence [15].

Two main approaches to measuring cyber-violence and cyber-bullying can be found in the literature: global-item and specific-item measures, and a combination. In a global-item measure, it usually describes what cyber-bullying is, and then the participants asses how often they have conducted or experienced cyber-bullying [12]. This approach is based on the premise that the participants will be able to apply a description of general behavior to truly estimate all specific situations they face and to categorize them into categories of bullying or non-bullying behavior [16]. It is questionable how successful adolescents are at this. An additional reason to doubt their ability to assess their behavior or experience on a global-item is due to the fact that the percentage of adolescents who are categorized as perpetrators or victims is several times lower when measuring with a global-item scale than when measuring with a specific-item scale [16].

For that reason, using specific-item measures can prompt recognition that a person has taken part in some cyber-violent behavior they would not recall without a specific item as a recall cue. There are different underlying categories in this type of measure. Some scholars use categories of direct and indirect cyber-violence [17], others differentiate between verbal/written, visual/sexual, and violence through social inclusion [18], cyberforgery, cyber-verbal bullying, and hiding identity [19], or use widely cited Willard's typology [20] that includes inflaming and harassment, denigration, impersonation, outing and trickery, exclusion, and cyberstalking [21]. Some authors [21] point out the importance of the timeframe used and suggest using "the past school year". In our opinion, this can be very ambiguous since research can be conducted at the beginning, in the middle, or at the end of the school year. This motivated us to use "in the previous year" (calendar year) as a time frame. Along with using Willard's typology of cyber-violence, the Olweus measure of traditional bullying [22] often served as inspiration to develop measures of cyber-bullying [16]. Olweus and Limber consider cyber-bullying as just one form of 
bullying [23] which is a position that does not consider the special features that the Internet provides to the perpetrator, like the illusion of anonymity, lack of visual feedback on victim suffering, or asynchronicity [24].

Still, traditional bullying was often used in convergent validity studies [16], as well as measures of aggression in the physical world [19]. Starting from the problem behavior theory [25], the same factors (individual, family patterns, peers) can contribute to various risk behaviors, and it can be used to explain cyber-violence [26]. This theory is strongly compliant with Bronfenbrenner's theory [27]. The problem behavior theory prompted researchers to explore relations among different but connected risk behaviors online, like problematic Internet use and problematic gaming [28] and cyber-violence [29].

\subsection{Cyber-Violence in Relation to Psychosocial Functioning}

Along with the relation of cyber-violence to other online risk behavior, it is also related to various aspects of psycho-social functioning. One of them is self-esteem or the overall subjective evaluation of personal value. High self-esteem is a protective factor for both committing and experiencing cyber-violence [30], although individuals who can be categorized as perpetrators/victims have the lowest level of self-esteem, and perpetrators have a higher self-esteem than victims [31]. In addition, self-esteem contributes more significantly to explaining the variance of cyber-victimization than the variance of cyberbullying [32]. In a high-school sample, moderate negative correlation was found between self-esteem and involvement in cyber-bullying, whereas the correlations of this involvement with depression and anxiety were positive and of a large size [33].

Depression, anxiety, and stress are often used as indicators of psychosocial functioning, and have a large negative correlation with self-esteem [34]. This is expected since lower self-esteem characterizes both subclinical and clinical depression, accompanied with a pessimistic view of future success and depressive mood [35]. Anxiety should be differentiated both from depression and fear. It is an overwhelming and preoccupying anticipation of negative outcomes. It often has physical symptoms like nausea, sweating, or shaking [36], which are similar to physical symptoms of stress [37]. Still, stress as a reaction to the realization of a person in a situation that endangers their physical or psychological wellbeing differs from anxiety-the cause of stress is often known, whereas anxiety cannot be attributed to specific cause. Despite this, all three negative emotional moods are highly connected.

They are also related to cyber-violence. Depression predicts cyber-victimization one year later, but cyber-victimization is also connected to increased depression in that time period [38]. Although it is expected that cyber-victimization be correlated with depression, it could be surprising that depression is also correlated with cyber-bullying and that the coefficients are similar (0.24 for cyber-victimization, and 0.21 for cyber-bullying) [39]. It should be borne in mind that $13 \%$ of adolescents are both perpetrators and victims of cyber-violence, compared to $8 \%$ being solely perpetrators and $15 \%$ being solely victims [31]. In addition, perpetrators/victims have the highest results not only for depression, but also for anxiety and stress. Depression has been predicted by relational and physical aggression in the failure model [40]. Children and youth who are aggressive, especially if they use relational aggression, impair their social relationships with peers. Consequently, they are more prone to internalizing problems, depression included.

Both state and trait anxiety are related to cyber-victimization, but only state anxiety is related to cyber-aggressiveness [41]. Anxiety is higher in the perpetrators/victims and victims group than in the perpetrators group [42]. Stress, measured both by biological markers of stress and self-assessed, is higher among perpetrators/victims and victims than among perpetrators or bystanders [42].

As can be seen, involvement in cyber-violence has a detrimental role in psychological functioning. It is also connected to lower grades and more devices owned [31]. 


\subsection{The Present Study}

The aim of this research was to explore the psychometric properties of the revised Committing and Experiencing Cyber-Violence Scale: its latent structure, reliability, and descriptive statistics of underlying dimensions, as well as the relation of some known correlates of cyber-violence, like indicators of psychosocial functioning and online behavioral problems, with cyber-violence.

Using Çetin et al.'s scale [19] as a starting point, in 2015 the Committing and Experiencing Cyber-Violence Scale was developed [29,31]. In that procedure, some behaviors (e.g., Internet fraud) were omitted as non-typical for peer cyber-violence, and others were concretized or modernized. Experience with implementing a prevention program against cyber-violence in elementary school from 2015 until 2019, and feedback from program participants, made us aware that revision and modernization of the scale is needed. In the summer of 2020, 19 elementary and 19 high-school students evaluated the 2015 scale version, which was used as an insight on the suitability of existing items and suggesting new ones.

The new version of the Committing and Experiencing Cyber-Violence Scale led to two main goals in the present study. The first was to revise and explore the underlying structure, reliability, and descriptive statistics of latent dimensions of the revised Committing and Experiencing Cyber-Violence Scale. The second was to explore the contribution of socio-demographic variables (gender, number of family members, parents' level of education, and grades), Internet-related variables (amount of time online both on weekdays and weekends and the number of devices in the family), indicators of psychological functioning (self-esteem, depression, anxiety, and stress), and online behavioral problems (problematic Internet use and problematic online gaming) in the prediction of committing and experiencing cyber-violence.

\section{Materials and Methods}

\subsection{Participants}

The study involved 1725 participants aged 15 to 19 years $(\mathrm{M}=17.17$; $\mathrm{SD}=1.307)$, with $30.61 \%$ or 528 male participants. The invitation to participate in the research was published on social networks. The sample was convenient and self-selected since the research was conducted online. According to the age structure, $13.9 \%$ of the participants were aged 15 $(n=240), 18.4 \%$ or 317 participants were aged $16,23.1 \%$ were aged $17(n=398), 18$-year-olds were $26.3 \%(n=454)$ of participants, and 316 or $18.3 \%$ of them were 19 years old.

\subsection{Measures}

Major sociodemographic information (age, grade, type of school, gender, parental educational level, number of family members) and information regarding Internet use were collected (number of hours in online activities, both on weekdays and the weekend, number of ICT devices in their households, the device preferred for using the Internet).

\subsubsection{The Committing and Experiencing Cyber-Violence Scale-2021}

The Committing and Experiencing Cyber-Violence Scale-2021 (CECVS-2021) is a new version of the scale of the same name $[29,31]$. The scale was refined in a previous study in which children and young people $(n=38)$ assessed how appropriate the items were and proposed some adaptations (e.g., "I purposefully sent viruses by e-mail" to "I purposefully sent viruses via messages on social media" - examples are from the scale of action; there is an equivalent in the scale of experience) and suggested some new violent behaviors on the Internet that they noticed (e.g.,"Through something that seemed like a joke, a prank, false praise online"). Experts in the field $(n=3)$ suggested item shape and items that include hate speech. The final version has 34 items for committing cyberviolence, and as many items for experiencing cyber-violence. Participants responded on a five-point scale (1-never to 5 -always). The higher results indicate higher levels of committing/experiencing violence, and the overall score for each subscale is the average 
answer for each scale item (ranging from 1 to 5). Cronbach's $\alpha$ was 0.93 for committing and 0.94 for experiencing cyber-violence.

\subsubsection{The Depression Anxiety Stress Scale}

The Depression Anxiety Stress Scale (DASS-21) [35] is a 21-item questionnaire measuring three negative emotional states: depression, anxiety, and stress. The items were answered using a 4-point scale ( $1=$ does not apply to me at all, $4=$ applies to me very much or most of the time) to rate the extent to which they had experienced each state over the preceding week. A higher score represents greater distress. The reliability coefficients (Cronbach's $\alpha$ ) were 0.83 for depression, 0.78 for anxiety, and 0.84 for stress.

\subsubsection{The Rosenberg Self-Esteem Scale}

The Rosenberg Self-Esteem Scale (RSE) [43] measures global self-esteem. It has 10 items, and participants answered on a 4 -point scale $(1=$ strongly disagree, $4=$ strongly agree). A higher score indicates higher self-esteem. Cronbach's $\alpha$ was 0.80 .

\subsubsection{The Generalized Problematic Internet Use Scale 2}

The Generalized Problematic Internet Use Scale 2 (GPIUS) [44] contains 15 Likerttype items rated on a 6-point scale (from "definitely disagree" to "definitely agree"). The scale has six factors (preference for online social interaction, using the Internet for mood regulation, compulsive Internet use, cognitive preoccupation with the Internet, and negative outcomes due to Internet use). The overall GPIUS2 index score was computed as a linear combination of answers on each item, which resulted in scores ranging from 15 to 105. The scale was highly reliable $(\alpha=0.93)$.

\subsubsection{Problematic Online Gaming Questionnaire Short-Form}

The Problematic Online Gaming Questionnaire Short-Form (POGQ-SF) [45] measures six underlying dimensions of problematic gaming (i.e., preoccupation, overuse, immersion, social isolation, interpersonal conflicts, and withdrawal). It has 12 items, and participants answered on a five-point scale (1-never to 5-always). The overall level of problematic online gaming was calculated by summarizing answers on each item, and higher scores indicated more pronounced symptoms of gaming.

\subsection{Procedure}

The Ethics Committee of the Faculty of Humanities and Social Sciences in Osijek approved this research, and informed online consent was obtained from the participants. The data were collected during February 2021. The study was announced on SNS sites (e.g., Facebook, Instagram), with all information on the purpose and scope of research, the possibilities of obtaining feedback, and the possibility of obtaining a prize for participation (one participant selected per case received a prize of about EUR 50-HRK 400). Using online research and conventional sample was determined with ongoing epidemiological measures against COVID-19 (e.g., entering high school was forbidden even for parents, and COVID bubbles were used for schooling). The procedure that was used can cause self-selection bias. In addition, there was no information about participants who gave up before submitting their questionnaire. This was taken into account when interpreting the data.

\subsection{Analysis}

To explore the factor structure of the questionnaire, an exploratory factor analysis was performed. The analysis was performed separately for the item-subscale of committing and item-subscale of experiencing. To examine the contributions of different correlates to the explanation of cyber-violence variance, hierarchical regression analyses were performed separately for experiencing and committing cyber-violence as criteria. The same model was used in both analyses. 


\section{Results}

\subsection{Exploratory Factor Analysis}

The results of exploratory factor analysis for experiencing cyber-violence are shown in Table 1.

Table 1. Extracted principal components with Eigenvalues, percentage of explained variance, and parallel analysis criterion-experiencing cyber-violence subscale.

\begin{tabular}{|c|c|c|c|}
\hline \multirow[b]{2}{*}{ Component } & Initial Solution & \multirow[b]{2}{*}{ Eigenvalue } & Parallel Analysis \\
\hline & $\begin{array}{l}\% \text { of Variance } \\
\text { Explained }\end{array}$ & & $\begin{array}{c}\text { 95th Percentile of } \\
\text { Random Eigenvalues }\end{array}$ \\
\hline 1 & 35.707 & 12.140 & 1.268571 \\
\hline 2 & 6.528 & 2.220 & 1.234820 \\
\hline 3 & 4.149 & 1.411 & 1.213038 \\
\hline 4 & 3.925 & 1.334 & 1.193046 \\
\hline 5 & 3.897 & 1.325 & 1.174709 \\
\hline 6 & 3.078 & $1.046^{*}$ & 1.157576 \\
\hline 7 & 2.995 & $1.018 *$ & 1.140548 \\
\hline
\end{tabular}

* Eigenvalues for those two factors are lower than those obtained in parallel analysis.

For experiencing cyber-violence, the initial analysis shows that all 34 items had loadings over 0.40 . The Kaiser-Meyer-Olkin test indicated very good sampling adequacy $(\mathrm{KMO}=0.95)$. Principal component analysis was performed to determine latent factors and resulted in seven factors with an Eigenvalue greater than 1. The parallel analysis with the $95 \%$ percentile criterion indicated that only the first five factors should be used and they explained $54.2 \%$ of the variance. The extracted factors were rotated with the Varimax method.

The pattern matrix for the Experiencing subscale is shown in Table 2. Participants with high results for the first factor experienced various types of shaming (e.g., rude comments, gossiping, exclusion from groups), so this factor was named "Shaming" and it had 13 items. The second factor consisted of seven items that describe manipulation with information to cause harm behavior (abbr. "Information manipulation"). Participants with higher results on that factor experienced situations like their conversations being shared via screenshot without permission or being contacted by people who used a fake identity or other uses of the Internet to find out private information about participants. The third factor was called "Hate speech," had three items, and included insults, ridicule, and calls for attacks because of group affiliation. The fourth 7-item factor was called "Use of technology to cause harm" (abbr. "Technology abuse"). It involves hacking into profiles to destroy photos or posts, deliberately sending viruses through social networks, and extortion. The last factor was called "Sharing information about a person" (abbr. "Information sharing") and included sharing photos, videos, or embarrassing information about a person, and editing photos in a shameful way. There were four items in the fifth factor.

The extracted factors had low to moderate intercorrelations (Table 3). The internal consistency of factors ranged between 0.75 (for technology abuse) and 0.91 (for shaming).

Analyses were also performed on data from the Committing subscale. For committing cyber-violence, initial analysis shows that all 34 items had loadings over 0.35 (only two items had a loading lower than 0.40 , but were kept in the analysis as good indicators of specific cyber-violence behavior). The Kaiser-Meyer-Olkin test again indicated very good sampling adequacy $(\mathrm{KMO}=0.96)$. Principal component analysis was performed to determine latent factors and resulted in five factors with Eigenvalues greater than 1 , and the parallel analysis with a $95 \%$ percentile criterion indicated that only three factors should be used. The five-factor solution explained $57.6 \%$ of the variance, and the three-factor solution explained $50.7 \%$ of the Committing subscale variance. Since Eigenvalues for the fourth and fifth factors were slightly lower than those obtained in parallel analysis, it was decided to keep all five factors. The extracted factors were rotated with the Varimax method (Table 4). 
Table 2. Pattern matrix of CECVS—experiencing cyber-violence subscale.

\begin{tabular}{|c|c|c|c|c|c|}
\hline Item & 1 & 2 & 3 & 4 & 5 \\
\hline 4 & 0.761 & & & & \\
\hline 2 & 0.744 & & & & \\
\hline 1 & 0.742 & & & & \\
\hline 3 & 0.730 & & & & \\
\hline 6 & 0.639 & & & & \\
\hline 8 & 0.638 & & & & \\
\hline 9 & 0.628 & & & & \\
\hline 10 & 0.536 & & & & \\
\hline 7 & 0.530 & & & & \\
\hline 31 & 0.507 & & & & \\
\hline 5 & 0.466 & & & & \\
\hline 28 & 0.461 & & & & \\
\hline 11 & 0.408 & & & & \\
\hline 13 & & 0.671 & & & \\
\hline 22 & & 0.629 & & & \\
\hline 25 & & 0.557 & & & \\
\hline 24 & & 0.522 & & & \\
\hline 12 & & 0.503 & & & \\
\hline 21 & & 0.473 & & & \\
\hline 30 & & 0.437 & & & \\
\hline 33 & & & 0.748 & & \\
\hline 32 & & & 0.680 & & \\
\hline 34 & & & 0.672 & & \\
\hline 15 & & & & 0.742 & \\
\hline 29 & & & & 0.732 & \\
\hline 14 & & & & 0.652 & \\
\hline 26 & & & & 0.562 & \\
\hline 27 & & & & 0.518 & \\
\hline 23 & & & & 0.435 & \\
\hline 16 & & & & 0.433 & \\
\hline 18 & & & & & 0.799 \\
\hline 19 & & & & & 0.786 \\
\hline 17 & & & & & 0.604 \\
\hline 20 & & & & & 0.500 \\
\hline
\end{tabular}

Table 3. Factor intercorrelations-experiencing cyber-violence subscale.

\begin{tabular}{cccccc}
\hline Component & $\mathbf{1}$ & $\mathbf{2}$ & $\mathbf{3}$ & $\mathbf{4}$ & $\mathbf{5}$ \\
\hline Shaming & $0.91^{*}$ & 0.262 & -0.374 & -0.349 & -0.418 \\
Information manipulation & & $0.79 *$ & -0.308 & -0.316 & -0.362 \\
Hate speech & & & $0.81 *$ & 0.271 & 0.411 \\
Technology abuse & & & & $0.75 *$ & 0.364 \\
Information sharing & & & & & $0.81^{*}$ \\
\hline
\end{tabular}

*Values on the diagonal are Cronbach's $\alpha$ coefficients.

Table 4. Extracted principal components with Eigenvalues, percentage of explained variance, and parallel analysis criterion-committing cyber-violence subscale.

\begin{tabular}{|c|c|c|c|}
\hline \multirow[b]{2}{*}{ Component } & Initial Solution & \multirow[b]{2}{*}{ Eigenvalue } & Parallel Analysis \\
\hline & $\begin{array}{l}\% \text { of Variance } \\
\text { Explained }\end{array}$ & & $\begin{array}{c}\text { 95th Percentile of } \\
\text { Random Eigenvalues }\end{array}$ \\
\hline 1 & 38.275 & 12.631 & 1.268571 \\
\hline 2 & 8.140 & 2.686 & 1.234820 \\
\hline 3 & 4.277 & 1.411 & 1.213038 \\
\hline 4 & 3.549 & 1.171 & 1.193046 \\
\hline 5 & 3.408 & 1.125 & 1.174709 \\
\hline
\end{tabular}


The item distribution by factors shown in Table 5 differed significantly from the distribution for the Experiencing subscale. As can be seen from Table 6, the reliability for the fifth factor was 0.66. Efforts were made to name the factors, but theoretically, the distribution of items by factors for the Experiencing subscale is much more meaningful. Therefore, the item distribution by factors obtained for Experiencing was applied to this subscale. A reliability analysis was performed on the items distributed by factor, which for the Sharing factor was 0.87 , for Information manipulation was 0.72 , for Hate speech was 0.87 , for Technology abuse was 0.88 , and for Information sharing was 0.73 (Cronbach's $\alpha$ ).

Table 5. Pattern matrix of CECVS—committing cyber-violence subscale.

\begin{tabular}{|c|c|c|c|c|c|}
\hline Item & 1 & 2 & 3 & 4 & 5 \\
\hline 26 & 0.857 & & & & \\
\hline 27 & 0.803 & & & & \\
\hline 16 & 0.773 & & & & \\
\hline 15 & 0.764 & & & & \\
\hline 29 & 0.759 & & & & \\
\hline 21 & 0.661 & & & & \\
\hline 23 & 0.644 & & & & \\
\hline 17 & 0.608 & & & & \\
\hline 24 & 0.576 & & & & \\
\hline 9 & 0.491 & & & & \\
\hline 22 & 0.484 & & & & \\
\hline 20 & 0.391 & & & & \\
\hline 30 & & 0.736 & & & \\
\hline 1 & & 0.653 & & & \\
\hline 28 & & 0.587 & & & \\
\hline 6 & & 0.581 & & & \\
\hline 18 & & 0.544 & & & \\
\hline 19 & & 0.522 & & & \\
\hline 11 & & 0.476 & & & \\
\hline 31 & & 0.445 & & & \\
\hline 14 & & 0.434 & & & \\
\hline 10 & & & 0.674 & & \\
\hline 3 & & & 0.622 & & \\
\hline 5 & & & 0.597 & & \\
\hline 7 & & & 0.567 & & \\
\hline 4 & & & 0.565 & & \\
\hline 2 & & & 0.543 & & \\
\hline 8 & & & & 0.472 & \\
\hline 33 & & & & 0.742 & \\
\hline 32 & & & & 0.715 & \\
\hline 34 & & & & 0.687 & \\
\hline 12 & & & & & 0.809 \\
\hline 13 & & & & & 0.772 \\
\hline 25 & & & & & 0.385 \\
\hline
\end{tabular}

Table 6. Factor intercorrelations—committing cyber-violence subscale.

\begin{tabular}{cccccc}
\hline Component & $\mathbf{1}$ & $\mathbf{2}$ & $\mathbf{3}$ & $\mathbf{4}$ & $\mathbf{5}$ \\
\hline 1 & $0.91^{*}$ & 0.332 & 0.334 & 0.305 & 0.428 \\
2 & & $0.82^{*}$ & 0.376 & 0.350 & 0.330 \\
3 & & $0.83^{*}$ & 0.227 & 0.219 \\
4 & & & $0.87 *$ & 0.277 \\
5 & & & & $0.66^{*}$ \\
\hline * Vlues on the diagonal are Cronbach's $\alpha$ coefficients.
\end{tabular}

*Values on the diagonal are Cronbach's $\alpha$ coefficients.

Descriptive statistics for the Experiencing and Committing subscales factors are presented in Table 7. As is common with risk behaviors, most factors were positively dis- 
tributed (most individuals had low scores on these factors). In Appendix A, the scale in English and Croatian can be found.

Table 7. Descriptive statistics of Experiencing and Committing subscales.

\begin{tabular}{|c|c|c|c|c|c|c|c|}
\hline Subscale & Component & Min & $\operatorname{Max}$ & $\mathbf{M}$ & SD & Skewness & Kurtosis \\
\hline \multirow{6}{*}{ Experiencing } & Shaming & 1.00 & 4.77 & 1.53 & 0.553 & 1.67 & 3.81 \\
\hline & Information manipulation & 1.00 & 4.86 & 1.57 & 0.577 & 1.49 & 2.97 \\
\hline & Hate speech & 1.00 & 5.00 & 1.31 & 0.626 & 2.65 & 7.83 \\
\hline & Technology abuse & 1.00 & 4.86 & 1.24 & 0.381 & 3.38 & 17.43 \\
\hline & Information sharing & 1.00 & 5.00 & 1.34 & 0.548 & 2.48 & 8.84 \\
\hline & Total & 1.00 & 4.65 & 1.44 & 0.443 & 2.12 & 7.32 \\
\hline \multirow{6}{*}{ Committing } & Shaming & 1.00 & 5.00 & 1.35 & 0.403 & 2.38 & 9.45 \\
\hline & Information manipulation & 1.00 & 5.00 & 1.31 & 0.416 & 2.57 & 10.90 \\
\hline & Hate speech & 1.00 & 5.00 & 1.11 & 0.408 & 5.24 & 32.70 \\
\hline & Technology abuse & 1.00 & 5.00 & 1.08 & 0.281 & 7.26 & 66.40 \\
\hline & Information sharing & 1.00 & 5.00 & 1.16 & 0.399 & 3.99 & 22.30 \\
\hline & Total & 1.00 & 5.00 & 1.25 & 0.326 & 3.81 & 23.35 \\
\hline
\end{tabular}

\subsection{Explaination of Variance in Experiencing and Committing Cyber-Violence}

To explore the contribution of socio-demographic variables, Internet-related variables, indicators of psychological functioning, and online behavioral problems in the explanation of the variance in committing and experiencing of cyber-violence, hierarchical regression analyses were conducted. In the first step, gender, number of family members, parents' level of education, and grades were included. In the second step, information on the amount of time online both on weekdays and weekends and the number of devices in the family were added. In the third step, depression, anxiety, stress, and self-esteem were included. In the fourth step, problematic use of the Internet and problematic gaming were added. Prior to this, correlations between predictors and predictors with criteria were calculated (Table 8). The results of HRA are in Tables 9 and 10.

As can be seen in Table 8, most variables correlated significantly with the committing and experiencing of cyber-violence. In addition, experiencing and committing cyberviolence were strongly correlated. The exception was the number of family members and the father's level of education (the latter only for committing). There were quite high intercorrelations of the psychological functioning variables (self-esteem, depression, anxiety, and stress), which could cause the problem of multicollinearity.

The model explained a total of $21 \%$ of the variance of experience, with only $1 \%$ of the variance explained in the first step. The second step did not increase the explained variance at all, but the variables added in the third step explained as much as $18 \%$ of the variance, and fourth step explained an additional $2 \%$. By adding variables to psychological functioning, gender became a significant predictor (young men experienced more violence). Grades and the level of maternal education were positive predictors of experiencing cyberviolence (participants with better grades and more educated mothers experienced more violence). Participants who showed a higher level of depression, anxiety, problematic Internet use, and problematic gaming also experienced more violence. Stress ceased to be a significant predictor with the introduction of the variables of problematic gaming and problematic Internet use-from Table 8 it can be seen that stress was correlated with both variables, but a more significant correlation was with problematic Internet use. Therefore, it can be assumed that the mediating effect of problematic Internet use is manifested in such a way that, from the participants who had higher levels of stress, those who used the Internet more problematically will experience higher levels of cyber-violence (as mediation effects were not the focus of this manuscript, no special mediation analysis was conducted). 
Table 8. Correlations between predictors and predictors with criteria.

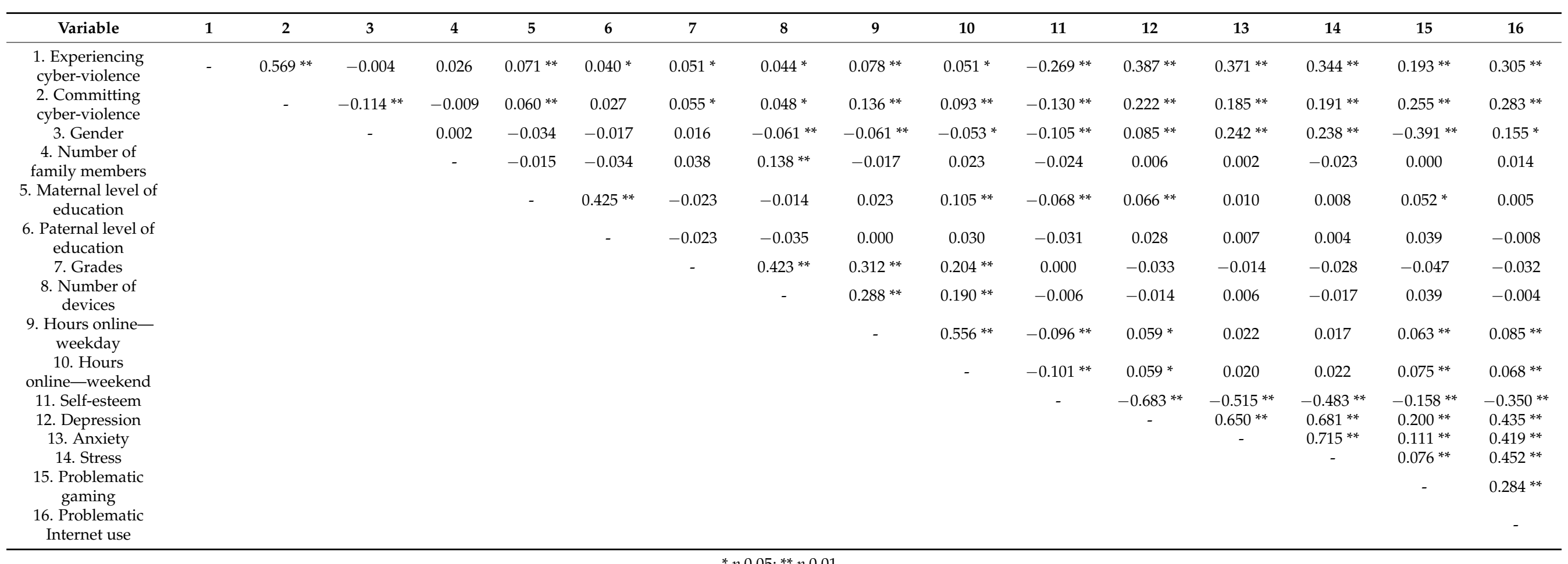


Table 9. HRA with experiencing as criteria.

\begin{tabular}{ccccc}
\hline Predictor & 1. Step & 2. Step & 3. Step & 4. Step \\
\hline Gender & -0.003 & 0.002 & $-0.086^{* *}$ & $-0.060^{*}$ \\
Number of family members & 0.025 & 0.026 & 0.026 & 0.024 \\
Maternal level of education & $0.067^{* *}$ & $0.065^{*}$ & $0.049^{*}$ & $0.049^{*}$ \\
Paternal level ofeducation & 0.013 & 0.014 & 0.013 & 0.013 \\
Grades & $0.052^{*}$ & 0.026 & 0.050 & $0.060^{*}$ \\
Number of devices & & 0.012 & 0.008 & 0.006 \\
Hours online-weekday & & $0.066^{*}$ & 0.045 & 0.035 \\
Hours online-weekend & & -0.001 & -0.013 & -0.018 \\
Self-esteem & & 0.022 & 0.035 \\
Depression & & & $0.218^{* *}$ & $0.188^{* *}$ \\
Anxiety & & & $0.200^{* *}$ & $0.178^{* *}$ \\
Stress & & & & 0.062 \\
Problematic gaming & & & & $0.078^{* *}$ \\
Problematic & & & & $0.120^{* *}$ \\
Internet use & 0.01 & 0.00 & 0.18 & 0.02 \\
$\triangle R^{2}$ & 0.01 & 0.01 & 0.19 & 0.21 \\
$R^{2}$ & $2.90^{*}$ & 2.38 & $93.08^{* *}$ & $20.85^{* *}$ \\
$F$ & & & &
\end{tabular}

Table 10. HRA with committing as criteria.

\begin{tabular}{ccccc}
\hline Predictor & 1. Step & 2. Step & 3. Step & 4. Step \\
\hline Gender & $-0.113^{* *}$ & $-0.105^{* *}$ & $-0.157^{* *}$ & $-0.112^{* *}$ \\
Number of family members & -0.010 & -0.007 & -0.004 & -0.008 \\
Maternal level of education & $0.057^{*}$ & 0.052 & 0.044 & 0.045 \\
Paternal level of education & 0.001 & 0.003 & 0.002 & 0.002 \\
Grades & $0.059^{*}$ & 0.020 & 0.035 & $0.052^{*}$ \\
Number of & & -0.001 & -0.004 & -0.007 \\
devices & & $0.114^{* *}$ & $0.104^{* *}$ & $0.088^{* *}$ \\
Hours online-weekday & & 0.015 & 0.009 & 0.001 \\
Hours online-weekend & & & 0.056 & $0.076^{* *}$ \\
Self-esteem & & $0.144^{* *}$ & $0.094^{* *}$ \\
Depression & & & $0.090 *$ & $0.055^{*}$ \\
Anxiety & & & $0.091 *$ & $0.052^{*}$ \\
Stress & & & & $0.134^{* *}$ \\
Problematic & & & & $0.196^{* *}$ \\
gaming & & 0.01 & 0.06 & 0.05 \\
Problematic & 0.02 & 0.03 & 0.10 & 0.15 \\
Internet use & 0.02 & $70.75^{* *}$ & $290.05^{* *}$ & $530.73^{* *}$ \\
$\triangle R^{2}$ & $60.78^{* *}$ & &
\end{tabular}

For committing cyber-violence as criteria, the model explained a total of $15 \%$ of the variance. In the first step, $2 \%$ of the variance was explained, $1 \%$ in the second step, and $6 \%$ and $5 \%$ of variance was explained in the third and fourth step, respectively. Participants who committed more cyber-violence were boys; those who spent more hours online on weekdays; those who had better grades; participants with higher self-esteem, higher levels of depression, anxiety, and stress; and those who were more prone to problematic Internet use and problematic gaming. It should be noted that self-esteem was positively correlated, whereas it was negatively correlated with committing cyber-violence, indicating multicollinearity effects of depression and self-esteem correlation on committing cyber-violence. 


\section{Discussion}

The first aim of this manuscript was to explore the new version of the Committing and Experiencing Cyber-Violence Scale. For this purpose, exploratory factor analyses for each of the subscales were conducted. The factor loadings were larger than 0.40 with the exception of two items in PCA for the committing cyber-violence subscale, and those item loadings were 0.391 and 0.385 , which is close to the recommended cut-off. Although it is possible to use a more restrictive approach (e.g., excluding all the items with factor loadings below 0.50 or 0.60 ), that would lead to a version of scale that is not informative relative to specific types of cyber-violent behavior. The final versions of the cyber-violence subscales have 34 items each, which should not be exhausting for participants. This is in line with the intention to produce a scale that explores specific cyber-violent behavior, and to use a specific-item approach where items are a form of retrieval cue for autobiographical memory. In exploratory factor analysis, a five-factor structure was extracted, but the item distribution per factor differed in its composition. The factor reliability analysis (the criteria was that factor and scale reliability should be above 0.70 ) and correspondence with known typologies [20] prevailed in the decision to give preference to the distribution obtained for the Experiencing cyber-violence subscale. The first factor, Shaming, includes behavior like inflaming, cyber denigration, and exclusion [20], whereas Information manipulation includes impersonation, outing [20], and non-consensual sexting [46].

The third factor, Hate speech, is included since information gained from qualitative research conducted in the summer of 2020 showed that adolescents report cases of hate speech when being asked about experiencing cyber-violence. It indicated that this behavior is related to other cyber-violent behavior directed toward an individual purely based on personal characteristics. Hate speech is defined as "all forms of expression which spread, incite, promote or justify racial hatred, xenophobia, anti-Semitism or other forms of hatred based on intolerance, including: intolerance expressed by aggressive nationalism and ethnocentrism, discrimination and hostility against minorities, migrants and people of immigrant origin" [47]. For instance, one high-school boy, when asked whether he had experienced cyber-violence, responded: "Well, various swearwords were directed toward me, my family, my religion and so on. I did not take it to heart, but I experienced it" [48]. Hate speech correlated negatively with experiencing Shaming and Information manipulation, and positively with Technology abuse and Information sharing. Three items describing hate speech were in one of the factors of the analysis conducted on the Committing cyberviolence subscale (the fourth factor), and it correlated positively with the four other factors in that analysis. It is possible that committing hate speech correlated with other cyberviolent behavior as a form of online aggressive behavior, but group membership was not as important for gossiping or impersonation (it is probably more connected with the abuse of some behavior or the characteristics a person manifests).

The fourth factor is named Technology abuse and it includes, as described by Willard [20], cyberstalking and online harassment. Information sharing is the name of the last factor, and a part of it is the behavior from Willard's outing and misinformation categories [20]. Those five factors encompass three categories of cyber-violence from the Council of Europe's Cybercrime Convention Committee's framework: cyberharassment, ICT-related violation of privacy, and ICT-related hate crimes [49].

What can be concluded from the descriptive statistics is that participants in this study relatively rarely experienced or committed cyber-violence (the average results for all factors and totals were in the range of answers of "never" to "rarely", and closer to never). Since data were collected online from a conventional sample, self-selection bias could have influenced in lowering the prevalence of cyber-violence among adolescents (e.g., participants with more cyber-violent behavior could decide disproportionally more that they did not want to participate in the study, and it is almost impossible to gain insight into attrition prior to submitting in this type of research). Still, these results are in concordance with results gained with a prior version of this scale from a representative sample [29,31]. In this research, the most frequent were experiencing and committing behaviors from 
Shaming and Information manipulation, and the rarest were experiencing and committing Technology abuse and Hate speech. This is understandable since those behaviors are under the influence of legal sanctions [50].

The committing and experiencing of cyber-violence correlated significantly and shared about $32 \%$ or one third of variance. This is in line with the finding that $15 \%$ of adolescents are categorized in the perpetrator/victim group [31].

The second aim was to explore the contribution of socio-demographic variables (gender, number of family members, parents' level of education, and grades), Internet-related variables (amount of time online both on weekdays and weekends and the number of devices in the family), indicators of psychological functioning (self-esteem, depression, anxiety, and stress), and online behavioral problems (problematic Internet use and problematic online gaming) in the explanation of the variance of the committing and experiencing of cyber-violence. It was found that gender (male), grades, maternal education, depression, anxiety, stress, problematic Internet use, and problematic gaming were positive predictors of experiencing cyber-violence. For committing, significant predictors were gender (male), grades, hours spent online on weekdays, depression, anxiety, stress, problematic Internet use, and problematic gaming were positive predictors. Based on the criteria of explained variance, the model was more suitable for explaining variance of experiencing than committing cyber-violence ( $21 \%$ compared to $15 \%$ of explained variance, respectively).

This could be attributed to variables of psychosocial functioning (self-esteem, depression, anxiety, and stress), since those four variables explained $18 \%$ of the $21 \%$ of experiencing variance, three times more than they contributed to explaining variance of committing cyber-violence $(6 \%)$. Since some research only explores the relationship between negative emotional states and cyber-victimization [39], or it was found to be less potent in explaining cyber-bullying [41], it is clear that experiencing cyber-violence is related to elevated emotional distress. However, the data supporting the failure model [40] that explains the interrelation among aggression and depression in a way that prior aggression elevates depression, probably through the disruption of social relationships, indicate the possibility that committing cyber-violence could also be detrimental for mental health. Prior data [31] indicate that it is stressful.

Only gender, grades, and maternal education proved to be significant predictors from the socio-demographic group of variables in the model, and those variables explained 1-2\% of the criterion variance. Boys reported higher levels of both committing and experiencing cyber-violence. Although it is well known that boys commit more cyber-violence [31], gender differences for experiencing are not as conclusive. Some data $[31,51]$ support that girls experience more cyber-violence, whereas others suggest that boys are more prone to cyber-victimization [52-54]. It should be kept in mind that this research was conducted on a convenient, self-selected sample with a gender imbalance, and this requires caution in interpretation. It was unexpected that higher grades and higher maternal education be connected with higher involvement in cyber-violence since academic success and parental education are found to be protective factors [30]. Since those two variables correlated positively with the number of devices and hours online, it is possible that lower maternal supervision due to maternal workload was an underlying mechanism. Good parental monitoring [55] proved to be a protective factor from both committing and experiencing cyber-violence.

Although problematic Internet use and problematic online gaming were significant positive predictors for both committing and experiencing cyber-violence, their contribution was 2.5 times bigger for committing than for explaining. Still, the amount of explained variance was low for both criteria ( $5 \%$ and $2 \%$, respectively). This indicates that online behavioral problems are different behaviors [28], although they share some common variance and correlate with common personal features, which is in line with the problem behavior theory [25]. Both problematic online gaming [25,45] and problematic Internet use [44] are forms of addictive behaviors, and the harm they cause is directed mainly toward the person who manifests them (and somewhat toward their significant others). Cyber-violence by 
definition is directed against others. For that reason, a higher correlation between problematic Internet use and variables measuring negative emotional mood (depression, anxiety, and stress) than the correlation of cyber-violence (especially the committing of it) with negative emotional mood variables is understandable. For committing cyber-violence, other variables, like the dark triad, could be more relevant [56].

This study demonstrates some of the characteristics of the revised cyber-violence scale. It is important that the revision of the scale use a participative approach. Still, in the circumstances related to the pandemic (very limited access to school; even PTA meetings were only online) forced the authors to conduct their research online and to use a convenient sample. When lockdown measures allow it, the research is expected to be replicated on a representative sample. A convenient and self-selected sample was also imbalanced in terms of gender, which could have affected the results. In future research, it would be good to add variables measuring parental monitoring, traditional aggression, or some personal traits like loneliness, empathy, and the dark triad, especially psychopathy.

\section{Conclusions}

The revised version of the cyber-violence scale has a five-factor underlying structure: Shaming, Information manipulation, Hate speech, Technology abuse, and Information sharing. Committing and experiencing cyber-violence are rare and highly connected behaviors. They share most of the significant predictors: gender, grades, hours spent online on weekdays, depression, anxiety, stress, problematic Internet use, and problematic gaming. Those who commit or experience cyber-violence more are more depressed, anxious, and stressed; more prone to problematic Internet use and problematic online gaming; and spend more hours online on weekdays, but they also have better grades and better educated mothers. Experiencing cyber-violence is more connected with lower indicators of psychosocial functioning, and those variables explained a similar amount of committing cyber-violence variance as online behavioral problems. Boys are more prone to both committing and experiencing cyber-violence. Maternal education could act through lower maternal supervision due to a higher workload. Future research should include parental and family functioning variables, personal trait variables, and variables measuring other forms of aggression toward others. Still, these results suggest that the mental health of youth involved in cyber-violence is jeopardized, especially those youth who experience cyber-violence. Although it is a relatively rare behavior, this warns us that preventive action should be continuously undertaken.

Funding: This research received no external funding.

Institutional Review Board Statement: The study was conducted according to the guidelines of the Declaration of Helsinki, and approved by the Ethics Committee of Faculty of Humanities and Social Science J. J. Strossmayer University of Osijek (protocol code 602-04/20-04/116; 2158-83-07-20-3, date of approval: 20 September 2020).

Informed Consent Statement: Informed consent was obtained from all subjects involved in the study.

Data Availability Statement: Data supporting reported results can be found with authors per demand.

Conflicts of Interest: The authors declare no conflict of interest. 


\section{Appendix A}

Table A1. The Committing and Experiencing Cyber-Violence Scale-2021 (CECVS-2021, Šincek, 2021). Translation is only for informative purposes; it is not translated per standard procedure for questionnaires.

\begin{tabular}{|c|c|c|c|}
\hline Instructions & $\begin{array}{l}\text { In Front of You Are Claims about } \\
\text { Uncomfortable Experiences We Can Have Online. } \\
\text { You Need to Answer Whether Something Described } \\
\text { in These Claims Happened to You in the Previous } \\
\text { Year. } \\
\text { 1-Never } \\
\text { 2-Rarely } \\
\text { 3-Sometimes } \\
\text { 4-Often } \\
\text { 5-Always }\end{array}$ & $\begin{array}{c}\text { The Following Are Claims Describing Less } \\
\text { Desirable Ways of Online Behavior. On a } \\
\text { Five-Degree Scale, Assess How Often You } \\
\text { Behaved Like This in the Previous Year. } \\
\text { Numbers on the Scales Have the Following } \\
\text { Meaning: } \\
\text { 1-Never } \\
\text { 2-Rarely } \\
\text { 3-Sometimes } \\
\text { 4-Often } \\
\text { 5-Always" } \\
\text { Others" Refers to the Peers You Know in Person } \\
\text { or Have Been in Contact with Online }\end{array}$ & Factor \\
\hline 1 & I was gossiped about online. & I gossiped about others online. & Shaming \\
\hline 2 & $\begin{array}{l}\text { Others referred to me (or mentioned me) online using } \\
\text { nicknames that made me upset. }\end{array}$ & $\begin{array}{l}\text { I referred to others online using nicknames that } \\
\text { made them upset. }\end{array}$ & Shaming \\
\hline 3 & $\begin{array}{l}\text { While talking with me or about me online, they used } \\
\text { offensive expressions and symbols. }\end{array}$ & $\begin{array}{l}\text { I used expressions and symbols online in } \\
\text { order to offend somebody online. }\end{array}$ & Shaming \\
\hline 4 & I was mocked online. & I mocked others online. & Shaming \\
\hline 5 & $\begin{array}{l}\text { I got anonymous negative comments online (e.g., } \\
\text { YouTube, TikTok). }\end{array}$ & $\begin{array}{l}\text { I left anonymous negative comments online (e.g., } \\
\text { YouTube, TikTok). }\end{array}$ & Shaming \\
\hline 6 & Something I posted online was ridiculed. & I ridiculed content others posted online. & Shaming \\
\hline 7 & $\begin{array}{l}\text { They wrote offensive comments under my online } \\
\text { posts. }\end{array}$ & $\begin{array}{l}\text { I wrote offensive comments under others' online } \\
\text { posts. }\end{array}$ & Shaming \\
\hline 8 & $\begin{array}{c}\text { They used humiliating expressions for me online (e.g., } \\
\text { you're stupid, what are those } \\
\text { pictures you posted, four-eyes, skinny ... ) }\end{array}$ & $\begin{array}{c}\text { I used humiliating expressions for others online } \\
\text { (e.g., you're stupid, what are those } \\
\text { pictures you posted, four-eyes, skinny ... ) }\end{array}$ & Shaming \\
\hline 9 & They spread falsehoods about me online. & I spread falsehoods about others online. & Shaming \\
\hline 10 & $\begin{array}{l}\text { They wanted to exclude me or have excluded me from } \\
\text { an online group. }\end{array}$ & I excluded others from online groups. & Shaming \\
\hline 11 & $\begin{array}{l}\text { I was publicly assessed (e.g., proclaimed the } \\
\text { prettiest/ugliest/most boring) online. }\end{array}$ & $\begin{array}{l}\text { I publicly assessed others (e.g., proclaimed the } \\
\text { prettiest/ugliest/most boring) online. }\end{array}$ & Shaming \\
\hline 12 & $\begin{array}{l}\text { They did not want to tell me who they were while } \\
\text { contacting me online. }\end{array}$ & $\begin{array}{l}\text { I hid my identity online while contacting another } \\
\text { person. }\end{array}$ & $\begin{array}{l}\text { Information } \\
\text { manipulation }\end{array}$ \\
\hline 13 & $\begin{array}{l}\text { They reached out to me from profiles with a made-up } \\
\text { identity (presenting as somebody else, fake profile). }\end{array}$ & $\begin{array}{l}\text { I used a made-up identity online (presenting as } \\
\text { somebody else, fake profile). }\end{array}$ & $\begin{array}{l}\text { Information } \\
\text { manipulation }\end{array}$ \\
\hline 14 & $\begin{array}{l}\text { They entered my online profiles/accounts without my } \\
\text { permission. }\end{array}$ & $\begin{array}{l}\text { I entered others' online profiles/accounts online } \\
\text { without their permission. }\end{array}$ & $\begin{array}{l}\text { Technology } \\
\text { abuse }\end{array}$ \\
\hline 15 & $\begin{array}{l}\text { They broke into my online profiles/accounts in order } \\
\text { to post something bad in my name or delete/destroy } \\
\text { some of my earlier posts. }\end{array}$ & $\begin{array}{l}\text { I broke into others' online profiles/accounts in } \\
\text { order to post something bad in their name of } \\
\text { delete/destroy some of the earlier posts by that } \\
\text { person. }\end{array}$ & $\begin{array}{l}\text { Technology } \\
\text { abuse }\end{array}$ \\
\hline 16 & $\begin{array}{l}\text { I was purposefully sent viruses via messages on social } \\
\text { media. }\end{array}$ & $\begin{array}{l}\text { I purposefully sent viruses via messages on social } \\
\text { media. }\end{array}$ & $\begin{array}{l}\text { Technology } \\
\text { abuse }\end{array}$ \\
\hline 17 & $\begin{array}{l}\text { They posted private, sensitive, or } \\
\text { embarrassing information about me online. }\end{array}$ & $\begin{array}{c}\text { I posted private, sensitive, or } \\
\text { embarrassing information about others online. }\end{array}$ & $\begin{array}{l}\text { Information } \\
\text { sharing }\end{array}$ \\
\hline 18 & They shared my videos online without my permission. & $\begin{array}{l}\text { I shared another person's videos online } \\
\text { without the permission of that person. }\end{array}$ & $\begin{array}{l}\text { Information } \\
\text { sharing }\end{array}$ \\
\hline 19 & They shared my photos online without my permission. & $\begin{array}{l}\text { I shared another person's photos online } \\
\text { without the permission of that person. }\end{array}$ & $\begin{array}{l}\text { Information } \\
\text { sharing }\end{array}$ \\
\hline 20 & My photos were edited in an offensive way. & $\begin{array}{l}\text { I edited another person's photos in an offensive } \\
\text { way online. }\end{array}$ & $\begin{array}{l}\text { Information } \\
\text { sharing }\end{array}$ \\
\hline
\end{tabular}


Table A1. Cont.

\begin{tabular}{|c|c|c|c|}
\hline Item Number & $\begin{array}{l}\text { In Front of You Are Claims about } \\
\text { Uncomfortable Experiences We Can Have Online. } \\
\text { You Need to Answer Whether Something Described } \\
\text { in These Claims Happened to You in the Previous } \\
\text { Year. } \\
\text { 1-Never } \\
\text { 2-Rarely } \\
\text { 3-Sometimes } \\
\text { 4-Often } \\
\text { 5-Always }\end{array}$ & $\begin{array}{l}\text { The Following Are Claims Describing Less } \\
\text { Desirable Ways of Online Behavior. On a } \\
\text { Five-Degree Scale, Assess How Often You } \\
\text { Behaved Like This in the Previous Year. } \\
\text { Numbers on the Scales Have the Following } \\
\text { Meaning: } \\
\text { 1-Never } \\
\text { 2-Rarely } \\
\text { 3-Sometimes } \\
\text { 4-Often } \\
\text { 5-Always" } \\
\text { Others" Refers to the Peers You Know in Person } \\
\text { or Have Been in Contact with Online }\end{array}$ & Factor \\
\hline 21 & $\begin{array}{l}\text { I was made to talk about sex online, even though I did } \\
\text { not want to. }\end{array}$ & $\begin{array}{l}\text { I made others to talk about sex online, even though } \\
\text { they did not want to. }\end{array}$ & $\begin{array}{l}\text { Information } \\
\text { manipulation }\end{array}$ \\
\hline 22 & $\begin{array}{l}\text { I was forwarded photos of other people online } \\
\text { (without their permission) that } \\
\text { depicted sexual content. }\end{array}$ & $\begin{array}{l}\text { I forwarded other people's photos that } \\
\text { depicted sexual content online. }\end{array}$ & $\begin{array}{l}\text { Information } \\
\text { manipulation }\end{array}$ \\
\hline 23 & I was threatened and blackmailed online. & $\begin{array}{l}\text { I used the Internet to benefit to the detriment of } \\
\text { others. }\end{array}$ & $\begin{array}{l}\text { Technology } \\
\text { abuse }\end{array}$ \\
\hline 24 & $\begin{array}{l}\text { They talked to me online just so they could extract } \\
\text { private information or services from me (money, game } \\
\text { character, photos). }\end{array}$ & $\begin{array}{l}\text { I talked to others online so I could extract private } \\
\text { information or services from others (money, game } \\
\text { character, photos). }\end{array}$ & $\begin{array}{l}\text { Information } \\
\text { manipulation }\end{array}$ \\
\hline 25 & $\begin{array}{l}\text { They used the Internet to find out private information } \\
\text { about me (address, phone number). }\end{array}$ & $\begin{array}{l}\text { I used the Internet to find out private information } \\
\text { about others (e.g., address, phone number). }\end{array}$ & $\begin{array}{l}\text { Information } \\
\text { manipulation }\end{array}$ \\
\hline 26 & $\begin{array}{l}\text { They asked me to give them money online so they } \\
\text { would not embarrass me (blackmailed me). }\end{array}$ & $\begin{array}{l}\text { I asked others to give me money online so I would } \\
\text { not embarrass them (I blackmailed others). }\end{array}$ & $\begin{array}{l}\text { Technology } \\
\text { abuse }\end{array}$ \\
\hline 27 & $\begin{array}{l}\text { They used the Internet to trick me and take my } \\
\text { personal information or money. }\end{array}$ & $\begin{array}{l}\text { I used the Internet to trick others and take their } \\
\text { personal information or money. }\end{array}$ & $\begin{array}{l}\text { Technology } \\
\text { abuse }\end{array}$ \\
\hline 28 & $\begin{array}{l}\text { They made fun of my possessions (phone, clothes, } \\
\text { shoes ... ) online. }\end{array}$ & $\begin{array}{l}\text { I made fun of others' possessions (phone, clothes, } \\
\text { shoes ... ) online. }\end{array}$ & Shaming \\
\hline 29 & $\begin{array}{l}\text { They hacked my social media or gaming } \\
\text { profile. }\end{array}$ & $\begin{array}{l}\text { I hacked others' social media or gaming } \\
\text { profiles. }\end{array}$ & $\begin{array}{l}\text { Technology } \\
\text { abuse }\end{array}$ \\
\hline 30 & $\begin{array}{l}\text { They shared screenshots of my private conversations } \\
\text { without my permission. }\end{array}$ & $\begin{array}{l}\text { I shared screenshots of others' private } \\
\text { conversations without their permission. }\end{array}$ & $\begin{array}{l}\text { Information } \\
\text { manipulation }\end{array}$ \\
\hline 31 & $\begin{array}{c}\text { Through something that looked like a joke, a prank, } \\
\text { false praise, they actually tried to } \\
\text { humiliate me online. }\end{array}$ & $\begin{array}{l}\text { Through something that looked like a joke, a } \\
\text { prank, false praise, I actually tried to } \\
\text { humiliate another person online. }\end{array}$ & Shaming \\
\hline 32 & $\begin{array}{l}\text { They made fun of me for being a member of a certain } \\
\text { group (e.g., they wrote to me sheep *, gypsies, leftards } \\
* *, \text { cripple, four-eyes, and such). }\end{array}$ & $\begin{array}{l}\text { I made fun of others for being members of a } \\
\text { certain group (e.g., I wrote sheep, gypsies, leftards, } \\
\text { cripple, four-eyes, and such). }\end{array}$ & Hate speech \\
\hline 33 & $\begin{array}{l}\text { I was offended online just for being a member of a } \\
\text { certain group (e.g., they wrote that the members of my } \\
\text { group and me are dumb obedient sheep, smelly } \\
\text { gypsies, slow cripples, stupid female, and such). }\end{array}$ & $\begin{array}{l}\text { I offended others online just for being members of } \\
\text { a certain group (e.g., I wrote that they are dumb } \\
\text { obedient sheep, smelly gypsies, slow cripples, } \\
\text { stupid female, and such). }\end{array}$ & Hate speech \\
\hline 34 & $\begin{array}{l}\text { They wrote online that the members of my group and } \\
\text { me should be attacked, banished, or destroyed just for } \\
\text { being a member of a } \\
\text { certain group (e.g., banish migrants, send women to } \\
\text { the kitchen, send disabled people to special schools ... } \\
\text { ). }\end{array}$ & $\begin{array}{l}\text { I wrote online that some people should be } \\
\text { attacked, banished, or destroyed just for being a } \\
\text { member of a certain group (e.g., banish } \\
\text { migrants, send women to the kitchen, send } \\
\text { disabled people to special schools ... ). }\end{array}$ & Hate speech \\
\hline
\end{tabular}

* Shameful naming of people wearing a mask during the COVID-19 pandemic in Croatia is brnjičari-literally "muzzlers." It was replaced with the English expression "sheep" used to make fun of people for wearing a mask and following lockdown orders. ${ }^{* *}$ kradezeovci is a shameful nickname for member of the Croatian democratic union/Hrvatska demokratska zajednica: In Croatia they are called hadezeovci, from the Croatian way of spelling the abbreviation (HDZ) - but some people use krade (meaning "steal") instead of hade to mark the members and supporters of that political party as thieves. It was replaced with the English expression "leftard," a blend of "left" and "retard" used to offend people for being supporters of left-leaning political parties and the ideological beliefs often associated with said parties. In translation, it should be appropriately replaced with terms from another societal context; it should be something very widespread in a particular society (e.g., in Croatia, Roma people are the group widely racially discriminated against, and in other societies it could be another group - as the polite name for Roma people in Croatian is Rom, the term cd-rom is sometimes used as a hidden way to insult group members). Shaming 1, 2, 3, 4, 5, 6, 7, 8, 9, 10, 11, 28, 31. Information manipulation 12, 13, 21, 22, 24, 25, 30. Hate speech 32, $33,34$. Technology abuse 14, 15, 16, 23, 26, 27, 29. Information sharing 17, 18, 19, 20. 
Table A2. Skala činjenja i doživljavanja nasilja preko interneta-2021 (SČDNI-2021, Šincek, 2021).

\begin{tabular}{|c|c|c|c|}
\hline Uputa & $\begin{array}{c}\text { Ispred tebe se nalaze tvrdnje koje govore o } \\
\text { neugodnim iskustvima koje možemo } \\
\text { doživjeti na internetu. Trebaš odgovoriti je li } \\
\text { ti se nešto opisano u tvrdnjama dogodilo u } \\
\text { zadnjih godinu dana. } \\
\text { 1-nikada } \\
\text { 2-rijetko } \\
3 \text {-ponekad } \\
4 \text {-često } \\
5 \text {-uvijek }\end{array}$ & $\begin{array}{l}\text { Slijede tvrdnje koje opisuje neke manje } \\
\text { poželjne načine ponašanja na internetu. Na } \\
\text { skali od pet stupnjeva procijeni koliko često } \\
\text { si se ti tako ponašao/la u zadnjih godinu } \\
\text { dana. Brojevi na skalama imaju sljedeće } \\
\text { značenje: } \\
\text { 1-nikada } \\
\text { 2-rijetko } \\
\text { 3-ponekad } \\
\text { 4-često } \\
\text { 5-uvijek, } \\
\text { drugi“ se odnosi na vršnjake koje poznaješ } \\
\text { uživo ili si u kontaktu s njima preko } \\
\text { interneta }\end{array}$ & Faktor \\
\hline 1 & Ogovarali su me na internetu. & Ogovarao/la sam druge na internetu. & Posramljivanje \\
\hline 2 & $\begin{array}{l}\text { Obraćali su mi se (ili su me spominjali) na } \\
\text { internetu s nadimcima koji me uzrujaju. }\end{array}$ & $\begin{array}{l}\text { Druge sam na internetu nazivao/la nadimcima } \\
\text { koji ih uznemiruju. }\end{array}$ & Posramljivanje \\
\hline 3 & $\begin{array}{l}\text { U razgovoru sa mnom ili o meni na internetu } \\
\text { koristili su uvredljive izraze i simbole. }\end{array}$ & $\begin{array}{l}\text { Koristio/la sam izraze i simbole na internetu } \\
\text { kako bih uvrijedio nekog na internetu. }\end{array}$ & Posramljivanje \\
\hline 4 & Rugali su mi se na internetu. & Rugao/la sam se drugima na internetu. & Posramljivanje \\
\hline 5 & $\begin{array}{l}\text { Dobivao/la sam anonimne ružne komentare } \\
\text { na internetu (npr. YouTube, TikTok). }\end{array}$ & $\begin{array}{c}\text { Ostavljao/la sam anonimno ružne komentare } \\
\text { na internetu (npr. YouTube, TikTok). }\end{array}$ & Posramljivanje \\
\hline 6 & $\begin{array}{l}\text { Ismijavali su nešto što sam objavio/la na } \\
\text { internetu. }\end{array}$ & $\begin{array}{c}\text { Ismijavao/la sam sadržaje koje bi drugi } \\
\text { objavili na internetu. }\end{array}$ & Posramljivanje \\
\hline 7 & $\begin{array}{l}\text { Pisali su uvredljive komentare ispod mojih } \\
\text { objava na internetu. }\end{array}$ & $\begin{array}{l}\text { Pisao/la sam drugima uvredljive komentare } \\
\text { ispod objava na internetu. }\end{array}$ & Posramljivanje \\
\hline 8 & $\begin{array}{c}\text { Na internetu su koristili izraze kojima su me } \\
\text { ponižavali (npr. glup si, kakve si to slike } \\
\text { objavio, očalko, mršavac ... ) }\end{array}$ & $\begin{array}{l}\text { Koristio/la sam ponižavajuće izraze koji su se } \\
\text { odnosili na druge na internetu (npr. glup si, } \\
\text { kakve si to slike objavio, očalko, mršavac ... ). }\end{array}$ & Posramljivanje \\
\hline 9 & Širili su neistine o meni na internetu. & Širio/la sam neistine o drugima na internetu. & Posramljivanje \\
\hline 10 & $\begin{array}{l}\text { Htjeli su me isključiti ili su me isključili iz neke } \\
\text { grupe na internetu. }\end{array}$ & Isključivao/la sam druge iz grupa na internetu. & Posramljivanje \\
\hline 11 & $\begin{array}{c}\text { Javno su me procjenjivali (npr. proglašavali } \\
\text { najljepšom/najružnijom/najdosadnijom } \\
\text { osobom) na internetu. }\end{array}$ & $\begin{array}{c}\text { Druge sam procjenjivao/la javno na internetu } \\
\text { (npr. proglašavao/la } \\
\text { najljepšom/najružnijom/najdosadnijom } \\
\text { osobom). }\end{array}$ & Posramljivanje \\
\hline 12 & $\begin{array}{l}\text { Nisu mi htjeli reći tko su oni dok su mi se } \\
\text { javljali na internetu. }\end{array}$ & $\begin{array}{l}\text { Skrivao/la sam identitet na internetu tijekom } \\
\text { kontakta s drugom osobom. }\end{array}$ & $\begin{array}{l}\text { Manipuliranje } \\
\text { informacijama }\end{array}$ \\
\hline 13 & $\begin{array}{c}\text { Drugi su mi se javljali s profila s izmišljenim } \\
\text { identitetom (predstavljali su se kao netko } \\
\text { drugi, lažni profil). }\end{array}$ & $\begin{array}{l}\text { Koristio sam izmišljeni identitet na internetu } \\
\text { (predstavljao/la se kao druga osoba, lažni } \\
\text { profil). }\end{array}$ & $\begin{array}{l}\text { Manipuliranje } \\
\text { informacijama }\end{array}$ \\
\hline 14 & $\begin{array}{l}\text { Ulazili su na moje profile/račune na internetu } \\
\text { bez mog dopuštenja. }\end{array}$ & $\begin{array}{l}\text { Ulazio/la sam na tuđe profile/račune na } \\
\text { internetu bez dopuštenja. }\end{array}$ & $\begin{array}{l}\text { Zloupotreba } \\
\text { tehnologije }\end{array}$ \\
\hline 15 & $\begin{array}{c}\text { Provalili su na moje profile/račune na } \\
\text { internetu kako bi nešto ružno objavili u moje } \\
\text { ime ili brisali/uništavali neke moje ranije } \\
\text { objave. }\end{array}$ & $\begin{array}{c}\text { Provalio/la sam na tuđe profile/račune na } \\
\text { internetu kako bi nešto ružno objavio/la u } \\
\text { tuđe ime ili brisao/la neke ranije objave te } \\
\text { osobe. }\end{array}$ & $\begin{array}{l}\text { Zloupotreba } \\
\text { tehnologije }\end{array}$ \\
\hline 16 & $\begin{array}{c}\text { Namjerno su mi slali viruse putem poruka na } \\
\text { društvenim mrežama. }\end{array}$ & $\begin{array}{c}\text { Namjerno sam slao/la viruse putem poruka na } \\
\text { društvenim mrežama. }\end{array}$ & $\begin{array}{l}\text { Zloupotreba } \\
\text { tehnologije }\end{array}$ \\
\hline
\end{tabular}


Table A2. Cont.

\begin{tabular}{|c|c|c|c|}
\hline Uputa & $\begin{array}{c}\text { Ispred tebe se nalaze tvrdnje koje govore o } \\
\text { neugodnim iskustvima koje možemo } \\
\text { doživjeti na internetu. Trebaš odgovoriti je li } \\
\text { ti se nešto opisano u tvrdnjama dogodilo u } \\
\text { zadnjih godinu dana. } \\
\text { 1-nikada } \\
\text { 2-rijetko } \\
3 \text { - ponekad } \\
4 \text {-često } \\
5 \text { - uvijek }\end{array}$ & $\begin{array}{l}\text { Slijede tvrdnje koje opisuje neke manje } \\
\text { poželjne načine ponašanja na internetu. Na } \\
\text { skali od pet stupnjeva procijeni koliko često } \\
\text { si se ti tako ponašao/la u zadnjih godinu } \\
\text { dana. Brojevi na skalama imaju sljedeće } \\
\text { značenje: } \\
\text { 1-nikada } \\
\text { 2-rijetko } \\
3 \text {-ponekad } \\
4 \text { - često } \\
5 \text {-uvijek, } \\
\text { drugi“ se odnosi na vršnjake koje poznaješ } \\
\text { uživo ili si u kontaktu s njima preko } \\
\text { interneta }\end{array}$ & Faktor \\
\hline 17 & $\begin{array}{l}\text { Objavili su privatne, osjetljive ili sramotne } \\
\text { informacije o meni na internetu. }\end{array}$ & $\begin{array}{l}\text { Objavljivao/la sam privatne, osjetljiva ili } \\
\text { sramotne } \\
\text { informacije o drugima na internetu. }\end{array}$ & $\begin{array}{l}\text { Dijeljenje } \\
\text { informacija }\end{array}$ \\
\hline 18 & $\begin{array}{l}\text { Dijelili su moje video snimke na internetu bez } \\
\text { mog dopuštenja. }\end{array}$ & $\begin{array}{l}\text { Dijelio/la sam video snimke druge osobe na } \\
\text { internetu bez dopuštenja te osobe. }\end{array}$ & $\begin{array}{l}\text { Dijeljenje } \\
\text { informacija }\end{array}$ \\
\hline 19 & $\begin{array}{c}\text { Dijelili su moje fotografije na internetu bez } \\
\text { mog dopuštenja. }\end{array}$ & $\begin{array}{l}\text { Dijelio/la sam fotografije druge osobe na } \\
\text { internetu bez dopuštenja te osobe. }\end{array}$ & $\begin{array}{l}\text { Dijeljenje } \\
\text { informacija }\end{array}$ \\
\hline 20 & $\begin{array}{l}\text { Moje fotografije su uređivali na uvredljiv } \\
\text { način. }\end{array}$ & $\begin{array}{l}\text { Uređivao/la sam fotografije drugih osoba na } \\
\text { uvredljiv način na internetu. }\end{array}$ & $\begin{array}{l}\text { Dijeljenje } \\
\text { informacija }\end{array}$ \\
\hline 21 & $\begin{array}{l}\text { Navodili su me da razgovaramo o seksu na } \\
\text { internetu, iako ja to nisam htio/la. }\end{array}$ & $\begin{array}{l}\text { Navodio sam druge na razgovor o seksu iako } \\
\text { oni to nisu htjeli. }\end{array}$ & $\begin{array}{l}\text { Manipuliranje } \\
\text { informacijama }\end{array}$ \\
\hline 22 & $\begin{array}{c}\text { Proslijeđivali su mi slike drugih ljudi (bez } \\
\text { dozvole tih ljudi), a seksualnog sadržaja, na } \\
\text { internetu. }\end{array}$ & $\begin{array}{l}\text { Proslijeđivao sam tuđe slike seksualnog } \\
\text { sadržaja na internetu. }\end{array}$ & $\begin{array}{l}\text { Manipuliranje } \\
\text { informacijama }\end{array}$ \\
\hline 23 & Prijetili su mi i ucjenjivali me preko interneta. & $\begin{array}{l}\text { Koristio/la sam internet da ostvarim korist na } \\
\text { štetu drugih. }\end{array}$ & $\begin{array}{l}\text { Zloupotreba } \\
\text { tehnologije }\end{array}$ \\
\hline 24 & $\begin{array}{l}\text { Dopisivali su se samnom na internetu samo } \\
\text { kako bi od mene dobili privatne informacije ili } \\
\text { neku uslugu (novac, lika u igrici, fotografije). }\end{array}$ & $\begin{array}{l}\text { Dopisivao sam se s drugima na internetu samo } \\
\text { kako bi od njih dobio/la privatne informacije } \\
\text { ili neku uslugu (novac, lika u igrici, fotografije). }\end{array}$ & $\begin{array}{l}\text { Manipuliranje } \\
\text { informacijama }\end{array}$ \\
\hline 25 & $\begin{array}{l}\text { Koristili su internet kako bi saznali privatne } \\
\text { informacije o meni (adresu, broj telefona ... ). }\end{array}$ & $\begin{array}{l}\text { Koristio sam internet kako bih saznao tuđe } \\
\text { privatne informacije (npr. adresu, broj } \\
\text { telefona). }\end{array}$ & $\begin{array}{l}\text { Manipuliranje } \\
\text { informacijama }\end{array}$ \\
\hline 26 & $\begin{array}{l}\text { Tražili su novac od mene na internetu kako me } \\
\text { ne bi osramotili (ucjenjivali su me). }\end{array}$ & $\begin{array}{c}\text { Tražio sam novac od drugih preko interneta } \\
\text { kako ih ne bih osramotio (ucjenjivao sam } \\
\text { druge). }\end{array}$ & $\begin{array}{l}\text { Zloupotreba } \\
\text { tehnologije }\end{array}$ \\
\hline 27 & $\begin{array}{l}\text { Koristili su internet kako bi na prevaru uzeli } \\
\text { moje osobne podatke ili novac. }\end{array}$ & $\begin{array}{l}\text { Koristio sam internet kako bi na prevaru uzeo } \\
\text { tuđe osobne-podatke ili novac. }\end{array}$ & $\begin{array}{l}\text { Zloupotreba } \\
\text { tehnologije }\end{array}$ \\
\hline 28 & $\begin{array}{l}\text { Ismijavali su moje stvari (mobitel, odjeću, } \\
\text { obuću) preko interneta. }\end{array}$ & $\begin{array}{l}\text { Ismijavao sam tuđe stvari (mobitel, odjeću, } \\
\text { obuću) preko interneta. }\end{array}$ & Posramljivanje \\
\hline 29 & $\begin{array}{l}\text { Hakirali su moj profil na društvenim mrežama } \\
\text { ili igricama. }\end{array}$ & $\begin{array}{l}\text { Hakirao sam tuđe profile na društvenim } \\
\text { mrežama ili igricama. }\end{array}$ & $\begin{array}{l}\text { Zloupotreba } \\
\text { tehnologije }\end{array}$ \\
\hline 30 & $\begin{array}{l}\text { Dijelili su screenshotove mojih privatnih } \\
\text { razgovora bez mog dopuštenja. }\end{array}$ & $\begin{array}{c}\text { Dijelio sam screenshotove tuđih razgovora bez } \\
\text { njihovog dopuštenja. }\end{array}$ & $\begin{array}{l}\text { Manipuliranje } \\
\text { informacijama }\end{array}$ \\
\hline 31 & $\begin{array}{c}\text { Kroz nešto što je izgledalo kao šala, fora, lažna } \\
\text { pohvala zapravo su me nastojali poniziti na } \\
\text { internetu. }\end{array}$ & $\begin{array}{c}\text { Kroz nešto što je izgledalo kao šala, fora, lažna } \\
\text { pohvala zapravo sam nastojao/la poniziti } \\
\text { drugu osobu na internetu. }\end{array}$ & Posramljivanje \\
\hline
\end{tabular}


Table A2. Cont.

\begin{tabular}{|c|c|c|c|}
\hline Uputa & $\begin{array}{l}\text { Ispred tebe se nalaze tvrdnje koje govore o } \\
\text { neugodnim iskustvima koje možemo } \\
\text { doživjeti na internetu. Trebaš odgovoriti je li } \\
\text { ti se nešto opisano u tvrdnjama dogodilo u } \\
\text { zadnjih godinu dana. } \\
\text { 1-nikada } \\
\text { 2-rijetko } \\
\text { 3-ponekad } \\
\text { 4-često } \\
5 \text {-uvijek }\end{array}$ & $\begin{array}{l}\text { Slijede tvrdnje koje opisuje neke manje } \\
\text { poželjne načine ponašanja na internetu. Na } \\
\text { skali od pet stupnjeva procijeni koliko često } \\
\text { si se ti tako ponašao/la u zadnjih godinu } \\
\text { dana. Brojevi na skalama imaju sljedeće } \\
\text { značenje: } \\
\text { 1-nikada } \\
\text { 2-rijetko } \\
\text { 3-ponekad } \\
4 \text {-često } \\
\text { 5-uvijek, } \\
\text { drugi“ se odnosi na vršnjake koje poznaješ } \\
\text { uživo ili si u kontaktu s njima preko } \\
\text { interneta }\end{array}$ & Faktor \\
\hline 32 & $\begin{array}{c}\text { Ismijavali su me samo zato što sam } \\
\text { pripadnik/ca neke grupe (npr. pisali su } \\
\text { mi-brnjičari, cd-romi, kradezeovci, šepavi, } \\
\text { očalko i slično). }\end{array}$ & $\begin{array}{l}\text { Ismijavao sam druge osobe samo zato što su } \\
\text { pripadnici neke grupe (npr. pisao brnjičari, } \\
\text { cd-romi, kradezeovci, šepavi, očalko i slično). }\end{array}$ & Govor mržnje \\
\hline 33 & $\begin{array}{l}\text { Vrijeđali su me na internetu samo zato što sam } \\
\text { pripadnik/ca neke grupe (npr. pisali su za } \\
\text { mene i članove moje grupe da smo zatucane } \\
\text { poslušne ovce, smrdljivi Cigani, zaostali } \\
\text { invalid, glupo žensko i slično). }\end{array}$ & $\begin{array}{l}\text { Vrijeđao sam druge osobe na internetu samo } \\
\text { zato što su pripadnici neke grupe (npr. pisao } \\
\text { za njih da su zatucane poslušne ovce, smrdljivi } \\
\text { Cigani, zaostali } \\
\text { invalid, glupo žensko i slično). }\end{array}$ & Govor mržnje \\
\hline 34 & $\begin{array}{l}\text { Drugi su pisali na internetu da treba napadati } \\
\text { ili protjerati ili uništiti mene i članove grupe } \\
\text { kojima pripadam samo zbog pripadnosti grupi } \\
\text { (npr. protjerati migrante, poslati žene u } \\
\text { kuhinju, invalide poslati u specijalne škole ... } \\
\text { ). }\end{array}$ & $\begin{array}{l}\text { Pisao sam na internetu da treba napadati ili } \\
\text { protjerati ili uništiti neke ljude samo zato što su } \\
\text { pripadnici neke grupe (npr. protjerati } \\
\text { migrante, poslati žene u kuhinju, invalide } \\
\text { poslati u specijalne škole ... . ). }\end{array}$ & Govor mržnje \\
\hline
\end{tabular}

Posramljivanje: 1, 2, 3, 4, 5, 6, 7, 8, 9, 10, 11, 28, 31. Manipuliranje informacijama: 12, 13, 21, 22, 24, 25, 30. Govor mržnje: 32,33 ,34. Zloupotreba tehnologije:14, 15, 16, 23, 26, 27, 29. Dijeljenje informacija: 17, 18, 19, 20.

\section{References}

1. Odluka o Obustavi Izvođenja Nastave u Visokim Učilištima, Srednjim i Osnovnim Školama te Redovnog Rada Ustanova Predškolskog Odgoja i Obrazovanja i Uspostavi Nastave na Daljinu [Decision on the Suspension of Teaching in Higher Education Institutions, Secondary and Primary Schools and the Regular Operation of Pre-School Education Institutions and the Establishment of Distance Learning]. Available online: https://narodne-novine.nn.hr/clanci/sluzbeni/2020_03_29_670.html (accessed on 1 June 2021).

2. Obraćanje Ravnateljima-14 Ožujka 2020. (Dan Broja Pi) (Address to the Principals-14 March 2020 (Pi Day). Available online: https:/ / mzo.gov.hr/UserDocsImages//dokumenti/Obrazovanje/Raspored//Transkript\%20obracanja\%20ministrice\% 20Divjak\%20ravnateljima\%20-\%2014.03.2020..pdf (accessed on 1 June 2021).

3. Odluka o Zabrani Napuštanja Mjesta Prebivališta i Stalnog Boravka u Republici Hrvatskoj [Decision on the Prohibition of Leaving the Place of Residence and Permanent Residence in the Republic of Croatia]. Available online: https: / / civilna-zastita.gov.hr/UserDocsImages/CIVILNA\%20ZA\%C5\%A0TITA/PDF_ZA\%20WEB/Odluka\%20o\%20zabrani\%20 napu\%C5\%A1tanja\%20prebivali\%C5\%A1ta....pdf (accessed on 1 June 2021).

4. Odluka o Stavljanju Izvan Upotrebe Dječjih Igrališta i Otvorenih Sportskih Igrališta [Decision on Putting Out of Use Children's Playgrounds and Outdoor Sports Playgrounds]. Available online: https://civilna-zastita.gov.hr/UserDocsImages/CIVILNA\%20 ZA\%C5\%A0TITA/PDF_ZA\%20WEB/Odluka\%20o\%20stavljanju\%20izvan \%20uporabe \%20dje \%C4\%8Djih\%20igrali\%C5\%A1 ta.pdf (accessed on 1 June 2021).

5. Dragun, R.; Veček, N.N.; Marendić, M.; Pribisalić, A.; Đivić, G.; Cena, H.; Polašek, O.; Kolčić, I. Have lifestyle habits and psychological well-being changed among adolescents and medical students due to COVID-19 lockdown in Croatia? Nutrients 2020, 13, 97. [CrossRef]

6. Vaillancourt, T.; Brittain, H.; Krygsman, A.; Farrell, A.H.; Landon, S.; Pepler, D. School bullying before and during COVID-19: Results from a population-based randomized design. Aggress. Behav. 2021, 47, 557-569. [CrossRef]

7. Piquero, A.R.; Jennings, W.G.; Jemison, E.; Kaukinen, C.; Knaul, F.M. Domestic violence during the COVID-19 pandemicEvidence from a systematic review and meta-analysis. J. Crim. Justice 2021, 74, 101806. [CrossRef] 
8. Lessard, L.M.; Puhl, R.M. Adolescent academic worries amid COVID-19 and perspectives on pandemic-related changes in teacher and peer relations. Sch. Psychol. 2021. online ahead of print. [CrossRef]

9. Suler, J.R.; Phillips, W.L. The bad boys of cyberspace: Deviant behavior in a multimedia chat community. CyberPsychol. Behav. 1998, 1, 275-294. [CrossRef]

10. Hinduja, S.; Patchin, J.W. Bullying Beyond the Schoolyard: Preventing and Responding to Cyberbullying, 2nd ed.; Corwin Press: Thousand Oaks, CA, USA, 2014; pp. 11-16.

11. Olweus, D. Bullying at School: What We Know and What We Can Do, 1st ed.; Blackwell Publishing: Malden, MA, USA, 1993; pp. 8-10.

12. Patchin, J.W.; Hinduja, S. Measuring cyberbullying: Implications for research. Aggress. Violent Behav. 2015, 23, 69-74. [CrossRef]

13. Dredge, R.; Gleeson, J.; De la Piedad Garcia, X. Cyberbullying in social networking sites: An adolescent victim's perspective. Comput. Hum. Behav. 2014, 36, 13-20. [CrossRef]

14. Šincek, D.; Duvnjak, I.; Tomašić-Humer, J. Empathy and gender effects on cyber-violence among Croatian youth. Psihologija 2020, 53, 377-392. [CrossRef]

15. Milić, M. Percepcija nasilja preko interneta iz perspektive učenika i nastavnika [Perception of cyber violence from the perspective of students and teachers]. Ljetop. Soc. Rada/Annu. Soc. Work 2020, 27, 113-150. [CrossRef]

16. Gradinger, P.; Strohmeier, D.; Spiel, C. Definition and measurement of cyberbullying. Cyberpsychol. J. Psychosoc. Res. Cyberspace 2010, $4,1$.

17. Buelga, S.; Postigo, J.; Martínez-Ferrer, B.; Cava, M.J.; Ortega-Barón, J. Cyberbullying among adolescents: Psychometric properties of the CYB-AGS cyber-aggressor Scale. Int. J. Environ. Res. Public Health 2020, 17, 3090. [CrossRef] [PubMed]

18. Lee, J.; Abell, N.; Holmes, J.L. Validation of measures of cyberbullying perpetration and victimization in emerging adulthood. Res. Soc. Work Pract. 2017, 27, 456-467. [CrossRef]

19. Çetin, B.; Yaman, E.; Peker, A. Cyber victim and bullying scale: A study of validity and reliability. Comput. Educ. 2011, 57, 2261-2271. [CrossRef]

20. Willard, N. Cyberbullying and Cyberthreats: Responding to the Challenge of Online Social Aggression, Threats, and Distress, 1st ed.; Research Press: Champaign, IL, USA, 2007; pp. 5-17.

21. Savage, M. Developing a Measure of Cyberbullying Perpetration and Victimization. Ph.D. Thesis, Arizona State University, Phoenix, AZ, USA, 2012.

22. Olweus, D. The Revised Olweus Bully/Victim Questionnaire; Research Center for Health Promotion (HEMIL Center), University of Bergen, Mimeo: Bergen, Norway, 1996; pp. 1-12.

23. Olweus, D.; Limber, S.P. Some problems with cyberbullying research. Curr. Opin. Psychol. 2018, 19, 139-143. [CrossRef] [PubMed]

24. Suler, J. The online disinhibition effect. Cyberpsychol. Behav. 2004, 7, 321-326. [CrossRef]

25. Jessor, R. The Origins and Development of Problem Behavior Theory. The Collected Works of Richard Jessor; Springer International Publishing: Cham, Switzerland, 2016; pp. 15-43.

26. Šincek, D.; Duvnjak, I.; Ručević, S. Provjera prikladnosti modela Jessorove Teorije problematičnog ponašanja za objašnjenje vršnjačkog nasilja preko interneta [Checking the suitability of Jessor's Theory of problematic behavior model for Internet peer violence explanation]. In Kretanja-Europski Realiteti-Teorijska Razmatranja, 1st ed.; Đukić, M., Ed.; Akademija za Umjetnost i Kulturu Sveučilišta, J.J. Strossmayera: Osijek, Croatia, 2021; pp. 150-162.

27. Bronfenbrenner, U. Ecological systems theory (1992). In Making Human Beings Human: Bioecological Perspectives on Human Development, 1st ed.; Bronfenbrenner, U., Ed.; Sage Publications Ltd.: Thousand Oaks, CA, USA, 2005; pp. $106-173$.

28. Király, O.; Griffiths, M.D.; Urbán, R.; Farkas, J.; Kökönyei, G.; Elekes, Z.; Tamas, D.; Demetrovics, Z. Problematic Internet use and problematic online gaming are not the same: Findings from a large nationally representative adolescent sample. Cyberpsychol. Behav. Soc. Netw. 2014, 17, 749-754. [CrossRef] [PubMed]

29. Šincek, D.; Tomašić Humer, J.; Duvnjak, I. Correlates of problematic gaming-is there support for proneness to risky behaviour? Psychiatr. Danub. 2017, 29, 302-312. [CrossRef]

30. Zych, I.; Farrington, D.P.; Ttofi, M.M. Protective factors against bullying and cyberbullying: A systematic review of meta-analyses. Aggress. Violent Behav. 2019, 45, 4-19. [CrossRef]

31. Šincek, D.; Duvnjak, I.; Milić, M. Psychological outcomes of cyber-violence on victims, perpetrators and perpetrators/victims. Hrvat. Rev. Rehabil. Istraživanja 2017, 53, 98-110. [CrossRef]

32. Patchin, J.W.; Hinduja, S. Cyberbullying and self-esteem. J. Sch. Health 2010, 80, 614-621. [CrossRef]

33. Baruah, H.; Dashora, P.; Parmar, A. Impact of cyberbullying on psychological health of adolescents. Int. J. Humanit. Soc. Sci. 2017, 6, 137-144.

34. Sinclair, S.J.; Siefert, C.J.; Slavin-Mulford, J.M.; Stein, M.B.; Renna, M.; Blais, M.A. Psychometric evaluation and normative data for the depression, anxiety, and stress scales-21 (DASS-21) in a nonclinical sample of US adults. Eval. Health Prof. 2012, 35, 259-279. [CrossRef] [PubMed]

35. Lovibond, P.F.; Lovibond, S.H. The structure of negative emotional states: Comparison of the Depression Anxiety Stress Scales (DASS) with the Beck Depression and Anxiety Inventories. Behav. Res. Ther. 1995, 33, 335-343. [CrossRef]

36. Nabi, H.; Hall, M.; Koskenvuo, M.; Singh-Manoux, A.; Oksanen, T.; Suominen, S.; Vahtera, J. Psychological and somatic symptoms of anxiety and risk of coronary heart disease: The health and social support prospective cohort study. Biol. Psychiatry 2010, 67, 378-385. [CrossRef] [PubMed] 
37. Guthrie, G.M.; Verstraete, A.; Deines, M.M.; Stern, R.M. Symptoms of stress in four societies. J. Soc. Psychol. 1975, 95, 165-172. [CrossRef]

38. Gámez-Guadix, M.; Orue, I.; Smith, P.K.; Calvete, E. Longitudinal and reciprocal relations of cyberbullying with depression, substance use, and problematic internet use among adolescents. J. Adolesc. Health 2013, 53, 446-452. [CrossRef] [PubMed]

39. Bonanno, R.A.; Hymel, S. Cyber Bullying and Internalizing Difficulties: Above and Beyond the Impact of Traditional Forms of Bullying. J. Youth Adolesc. 2013, 42, 685-697. [CrossRef] [PubMed]

40. Blain-Arcaro, C.; Vaillancourt, T. Longitudinal Associations between Depression and Aggression in Children and Adolescents. J. Abnorm. Child Psychol. 2017, 45, 959-970. [CrossRef]

41. Grigore, A.N.; Maftei, A. Exploring the Mediating Roles of State and Trait Anxiety on the Relationship between Middle Adolescents' Cyberbullying and Depression. Children 2020, 7, 240. [CrossRef]

42. Boca-Zamfir, M.; Turliuc, M.N. Cyberbullying among Romanian adolescents: The relationships between the cyberbullying status and depression, anxiety, and self-esteem. In Proceedings of the Fifth International Conference on Adult Education-Education for Values-Continuity and Context, Proceedings of CIEA; pp. 375-382.

43. Rosenberg, M. Conceiving the Self; Basic Books: New York, NY, USA, 1979.

44. Caplan, S.E. Theory and measurement of generalized problematic Internet use: A two-step approach. Comput. Hum. Behav. 2010, 26, 1089-1097. [CrossRef]

45. Pápay, O.; Urbán, R.; Griffiths, M.D.; Nagygyörgy, K.; Farkas, J.; Kökönyei, G.; Felvinczi, K.; Oláh, A.; Elekes, Z.; Demetrovics, Z. Psychometric properties of the problematic online gaming questionnaire short-form and prevalence of problematic online gaming in a national sample of adolescents. Cyberpsychol. Behav. Soc. Netw. 2013, 16, 340-348. [CrossRef]

46. Pampati, S.; Lowry, R.; Moreno, M.A.; Rasberry, C.N.; Steiner, R.J. Having a sexual photo shared without permission and associated health risks: A snapshot of nonconsensual sexting. JAMA Pediatr. 2020, 174, 618-619. [CrossRef] [PubMed]

47. Recommendation, no. R (97) 20 of the Committee of Ministers to Member States on "Hate Speech". Available online: https: / / rm.coe.int/1680505d5b (accessed on 14 June 2021).

48. Šincek, D. Kako naši mladi doživljavaju internet? [How Do Our Young People Experience the Internet?]. In Proceedings of the Festival Psihologije i Medija (The Festival Od Psychology and Media), Rijeka, Croatia, 17-18 September 2020.

49. Council of Europe; CyberCrime Convention Committee. Working Group on Cyberbullying and Other Forms of Online Violence, Especially against Women and Children (CBG): Mapping Study on Cyberviolence (Draft). Available online: https://rm.coe.int/tcy-2017-10-cbg-study/16808b72da (accessed on 17 June 2021).

50. Kazneni Zakon [Criminal Law]. Available online: https:/ / www.zakon.hr/z/98/Kazneni-zakon (accessed on 17 June 2021).

51. Slonje, R.; Smith, P.K. Cyberbullying: Another main type of bullying? Scand. J. Psychol. 2008, 49, 147-154. [CrossRef]

52. Raskauskas, J.; Stoltz, A.D. Involvement in traditional and electronic bullying among adolescents. Dev. Psychol. 2007, 43, 564-575. [CrossRef] [PubMed]

53. Welrave, M.; Heriman, W. Cyberbullying: Predicting Victimisation and Perpetration. Child. Soc. 2011, 25, 59-72. [CrossRef]

54. Šincek, D. Gender differences in cyber-bullying. In International Multidisciplinary Scientific Conference Social Sciences and Arts SGEM2014 Conference Proceedings; STEF92 Technology Ltd.: Sofia, Bulgaria, 2014; Volume 1, pp. 195-202. [CrossRef]

55. Kowalski, R.M.; Giumetti, G.W.; Schroeder, A.N.; Lattanner, M.R. Bullying in the digital age: A critical review and meta-analysis of cyberbullying research among youth. Psychol. Bull. 2014, 140, 1073-1137. [CrossRef] [PubMed]

56. Šincek, D.; Duvnjak, I.; Žigmundić, M. Doprinosi osobina ličnosti objašnjenju rizičnih ponašanja na internetu. In 24 Ramiro and Zoran Bujas Days; International Scientific Psychology Conference Book of Abstracts; Jelić, T., Ed.; Department of Psychology, Faculty of Humanities and Social Sciences, University of Zagreb: Zagreb, Croatia, 2019; p. 138. 